\title{
TANANYAG- ÉS OKTATÁSSZERVEZÉS A MŰSZAKI KÉPZÉSEKBEN
}

\section{ORGANIZATION OF CURRICULUM AND EDUCATION IN TECHNICAL TRAINING}

\author{
Bagyinszki Gyula ${ }^{1}$, Bitay Enikő2 \\ Debreceni Egyetem, Müszaki Kar, Debrecen, Magyarország \\ ${ }^{1}$ Óbudai Egyetem, Bánki Donát Gépész és Biztonságtechnikai Mérnöki Kar, Budapest, Magyarország, \\ bagyinszki.gyula@bgk.uni-obuda.hu \\ ${ }^{2}$ Sapientia - Erdélyi Magyar Tudományegyetem, Marosvásárhelyi Kar, Marosvásárhely, Románia, \\ ebitay@ms.sapientia.ro
}

\begin{abstract}
Proper management of the realization of the general and special training objectives of technical higher education makes it necessary to organize the curriculum and the educational process according to didactic, methodological aspects. Selection of curriculum elements with deductive and inductive approach and their horizontal and vertical arrangement are required. In addition, the curriculum concentration of a given subject, i.e. its connection to other subjects, must be taken into account. This article intends to add to this by raising some points.
\end{abstract}

Keywords: curriculum, deductive, inductive, horizontal, vertical.

\section{Összefoglalás}

A műszaki felsőoktatás általános és speciális képzési céljai megvalósításának helyes irányítása indokolttá teszi, hogy a tantervet és az oktatási folyamatot didaktikai, szakmódszertani szempontok szerint is szervezzük. Deduktív és induktív megközelítésű tananyagelemek kiválasztása, továbbá ezek horizontális és vertikális elrendezése válik szükségessé. Ezek mellett figyelembe kell venni az adott tantárgy tantervi koncentrációját, azaz más tantárgyakhoz való kapcsolódását is. Jelen cikk néhány szempont felvetésével kíván ehhez hozzájárulni.

Kulcsszavak: tanterv, deduktív, induktív, horizontális, vertikális.

\section{Tananyagszervezés}

A különböző szakirányokra, specializációkra való motiválás és előkészítés érdekében - a hozzájuk kötődő alaptárgyak keretében - célszerü a jellegzetes műszaki problémákat már a képzés kezdetétől bevinni a tantervi koncepcióba. Ezt szolgálják az asszociatív (egyesítő) tantervek illetve tananyagok. Lényegüket az 1 . ábra szemlélteti, összehasonlítva a két alapváltozattal: a deduktív (levezető, következtető) és az induktív (speciálisból általánosító) tantervekkel illetve tananyagokkal [1].

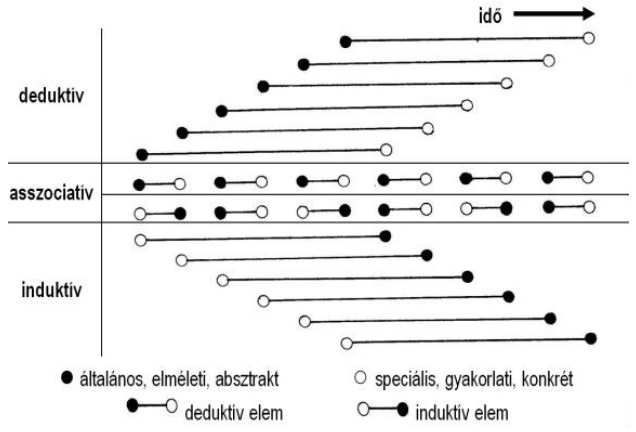

1. ábra. Tanterv illetve tananyag szerkezetek 
A deduktív megközelítés tehát ismert igaz állításokból vezet újabb igaz állításokhoz következtetés útján, míg az induktív megismerés egyedi megfigyelések alapján fogalmaz meg általános érvényü szabályokat. Az utóbbi révén létrejött új tudás nem tekinthető teljes bizonyossággal abszolút igaznak, csak valószínűleg igaznak (hipotetikusnak), mivel véges (kevés) számú eset megfigyelése alapján történt az általánosítás. Az induktív megközelítés összetett folyamat, melynek legfontosabb elemei: analógia keresés, szabályindukció, ellenpélda állítás, bizonyítás. Például induktív út a színfémek kristályosodási folyamatának oktatása lehűlési görbék felvétele illetve elemzése és a Gibbs-féle fázisszabály igazolása alapján. Deduktív útra példa a színfémek kristályosodási folyamatának oktatása adott lehülési görbe és a Gibbs-féle fázisszabály alapján. A deduktív eljárásra további példákkal is szolgál a 2. ábra [2].
A 2. ábrán említett struktúrák oktatását célzó tananyag-feldolgozás szempont-rendszere a következő:

- alapelv, alapfogalmak;

- technológiai paraméterek és számítások;

- eljárások és berendezések;

- alkalmazhatóság, előnyök, hátrányok, gazdaságosság;

- minőségirányítás, szükséges és célszerű anyagvizsgálatok;

- biztonságtechnika, környezetvédelem;

-hazai vonatkozások, nemzetközi összehasonlítás.

A tanítási tartalom kiválasztása és szervezése egyre inkább szakértői munkává, így minden szaktanár és oktatókollektíva feladatává válik, különféle tényezőcsoportok mérlegelésével (3. ábra) [3].

\begin{tabular}{|c|c|c|c|}
\hline & I. & II. & III. \\
\hline Lépések & $\begin{array}{c}\text { Az elözetes ismeretek } \\
\text { felfrissitése, új rendszerré } \\
\text { szervezése. } \\
\text { (pl. alakváltozás } \\
\text { mechanizmusának } \\
\text { átismétlése) }\end{array}$ & \begin{tabular}{|c|} 
Új fogalmak, alapelvek, \\
alapszabályok kialakítása. \\
A technológiák alapelveinek \\
oktatása. \\
(pl. képlékenyalakítás \\
elvének feldolgozása)
\end{tabular} & $\begin{array}{c}\text { Az új ismeretek alkalmazása, } \\
\text { az egyedi gyártás- } \\
\text { technológiák oktatása. } \\
\text { (pl. hengerlés, kovácsolás, ... } \\
\text { technológiáinak ismertetése) }\end{array}$ \\
\hline Módszerek & $\begin{array}{c}\text { Kérdésekkel feltárni az } \\
\text { elözetes ismeretek szintjét. } \\
\text { Kiegészíteni az ismereteket } \\
\text { beszélgetéssel, } \\
\text { feladatmegoldással. }\end{array}$ & \begin{tabular}{|} 
Tanári magyarázat és \\
szemléltetés, esetenként \\
üzemlátogatás az új \\
ismeretek feldolgozásában. \\
Feladatrendszeres oktatás az \\
alkalmazás fázisában.
\end{tabular} & $\begin{array}{c}\text { Tanári magyarázat, } \\
\text { beszélgetés. } \\
\text { Önálló ismeretfeldolgozás } \\
\text { irányító kérdéssor alapján } \\
\text { szakkönyvböl. } \\
\text { Önálló alkalmazás: feladatok } \\
\text { kidolgozása. }\end{array}$ \\
\hline Eredmények & $\begin{array}{l}\text { Új jártasságok az alap- } \\
\text { ismeretek alkalmazásában. }\end{array}$ & $\begin{array}{l}\text { Új fogalmak, összefüggések, } \\
\text { elvek, struktúrák elsajátitása. }\end{array}$ & $\begin{array}{l}\text { Jártasság a technológiai } \\
\text { ismeretek alkalmazásában. }\end{array}$ \\
\hline
\end{tabular}

2. ábra. Deduktív tananyag-feldolgozás

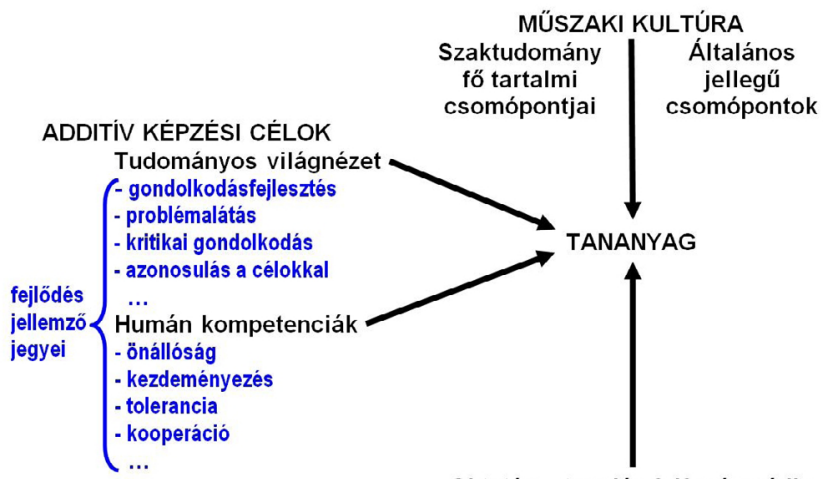

Oktatás - tanulás felfogásmódja MOTIVÁLÁS - AKTIVIZÁLÁS - DIFFERENCIÁLÁS

3. ábra. A tananyag-kiválasztás befolyásoló tényezői 
Az első tényező-csoportba tartozó additív képzési célok két kategóriája a tudományos „világnézet” és a humán kompetenciák, amelyek a tanítási-tanulási folyamat szervezése számára kellő stabilitást biztosítanak, ugyanakkor rugalmasan teret engednek a bekövetkező változások, megjelenő újdonságok befogadására, bizonyítandó az oktatásszervezés haladás-pártiságát és alkalmazkodó képességét. Ezek a célok sohasem egyirányú meghatározottságot jelentenek, hanem az oktatási eredmények, illetve minőségügyi folyamatok felől visszajövő jelzések regulatív (szabályozó) hatásait is magukba foglalják.

A második tényező-csoportot a műszaki kultúra fogalma foglalja össze, mint a szaktudományok és az anyagi, érintkezési (szociális) illetve szellemi objektivációkhoz való viszonyok összessége; azaz mindig dolgok (értékek) és tevékenységek (eredeti alkotás, gyakorlati használat, újraalkotó megformálás, elsajátítás, stb.) együttese.

A harmadik tényező-csoport az oktatás-tanulás felfogásmódja, amelynek a tananyagban való kifejezése hozzájárul ahhoz, hogy az egymástól igen különböző képességű, motivációjú, érdeklődésű hallgatók az elvárásoknak megfelelő és saját érdekeiket kielégítő módon tanulhassanak [3].

\section{Oktatásszervezés}

Az elvszerűen kiválasztott tananyagot meghatározott szempontok szerint osztályozni kell, mert csak így körvonalazódnak főbb szektorai, amelyek azután az oktatási-tanulási folyamat alapját képezhetik. A globálisan megjelölt müveltségi tartalmat tehát megfelelően el kell rendezni. Ezt az elrendezést alapvetően két irányból: horizontális és vertikális irányból lehet megközelíteni.

A vertikális megközelítés a tananyag konstrukciójában mutatkozó egymásutániságot kívánja realizálni, s az elrendezésnek ez az iránya szoros kapcsolatban van magával az oktatási rendszerrel, valamint a képzés szisztémájával. [4]

A horizontális megközelítés azt jelenti, hogy a tananyag egymás mellé rendelt és egymással kapcsolatban. lévő kisebb-nagyobb tömbjei a képzési folyamat irányítása szempontjából milyen témaegységekbe sorolhatók be. A horizontális elrendezés szoros összefüggésben van magának a tananyagnak a kiválasztásával, melynek struktúráját a 4. ábra szemlélteti.

A tantárgy és annak tananyaga nem valamely tudomány kisebbített változata, másolata, hanem a hallgatók leendő pályájára való - tudományos igényű és ugyanakkor gyakorlati hatékonyságú eligazításának eszköze.

Egy korszerű tanterv nem elszigetelt tantárgyi rendszerben gondolkodik, hanem tantárgyblokkok (modulok) - egymással összefüggő tantárgyak olyan magasabb egységei, amelyekben megmarad az egységet alkotó tárgyak relatív önállósága - rendszerének kialakítására törekszik.

Az egyes tantárgyak témáinak tanítása az egész blokk belső logikájának alárendelve történik és ez megköveteli a különböző szakterületű tanárok együttműködését [3].

Fontos szerepe van a tanterv készítésekor, ill. a tananyag kiválasztásakor a tantervi koncentrációnak, azaz fel kell térképezni a különböző tantárgyak kapcsolatait, hogy valamely tantárgyban bizonyos ismeretek feldolgozásához más tárgyakból szükséges meghatározott ismeretek mikor és milyen részletességgel kerülnek feldolgozásra.

Ez szükséges ahhoz, hogy a már meglévő ismeretekre építeni tudjunk és ezáltal elkerüljük a felesleges ismétlést (ami időigényes) illetve a még nem meglévő ismeretek feltétlenül szükséges hányadát [5] beépítsük az adott tantárgy anyagába. Az 5. ábrán példaképpen két szakmai alapozó tárgy tantervi koncentrációjának tartalmi kivonata látható.

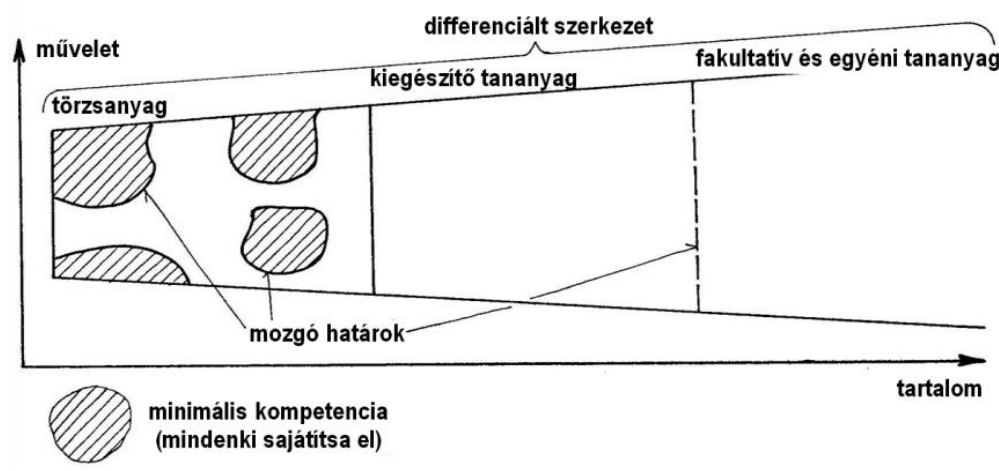

4. ábra. A tananyag struktúrája 


\begin{tabular}{|c|c|c|c|}
\hline & ANYAGTUDOMÁNY & ANYAGTECHNOLÓGIA & \\
\hline \multirow{2}{*}{$\begin{array}{c}\text { MATEMATIKA } \\
\text { vektoralgebra alapfogalmai, } \\
\text { egyenes és sík analitikus geometriája, } \\
\text { mátrixszámitás, tenzoralgebra, } \\
\text { differenciálszámítás és alkalmazásai, } \\
\text { integrálszámitás és alkalmazásai } \\
\text { függvényanalizis }\end{array}$} & $\begin{array}{l}\text { Anyagszerkezet: makro-, mikro-, } \\
\text { kristály- és atomi szerkezet } \\
\text { Anyagszerkezet vizsgálatok: vizuális, } \\
\text { roncsolásmentes, mikroszkópi } \\
\text { és elektronmikroszkópi }\end{array}$ & $\begin{array}{l}\text { Anyagelöállitás: } \\
\text { bioanyag-feldolgozás, } \\
\text { múanyaggyártás, } \\
\text { fémkohászat, } \\
\text { kerámiagyártás }\end{array}$ & \multirow{2}{*}{$\begin{array}{l}\text { MECHANIKA } \\
\text { feszültségi állapotok, } \\
\text { alakváltozási állapotok, } \\
\text { alakváltozási energia, } \\
\text { egyenértékũ feszültség, } \\
\text { merevségre méretezés, } \\
\text { szilárdságra méretezés }\end{array}$} \\
\hline & $\begin{array}{c}\text { Anyagválaszték: } \\
\text { bioanyagok, müanyagok, } \\
\text { fémek, kerámiák, kompozitok }\end{array}$ & $\begin{array}{c}\text { Alakadó technológiák: öntészet, } \\
\text { porkohászat és szinterkerámia-gyártás, } \\
\text { alakitás, forgácsolás, vágás }\end{array}$ & \\
\hline \multirow{2}{*}{$\begin{array}{c}\text { MÉRNÖKI FIZIKA } \\
\text { modellalkotás, statisztikai szemlélet, } \\
\text { anyag atomos szerkezete, } \\
\text { szabadelektrongáz modell, } \\
\text { szilárdtestfizika, } \\
\text { hôtan, } \\
\text { eletromosságtan, } \\
\text { mágnességtan, } \\
\text { optika, } \\
\text { akusztika }\end{array}$} & $\begin{array}{c}\text { Anyagtulajdonságok: } \\
\text { mechanikai, termikus, elektromos, } \\
\text { mágneses, optikai, akusztikai } \\
\text { Szakitóvizsgálat és keménységmérés; } \\
\text { Fizikai tulajdonságok vizsgálata }\end{array}$ & $\begin{array}{l}\text { Kötötechnológiák: } \\
\text { hegesztés, forrasztás, } \\
\text { ragasztás, mechanikus kötés }\end{array}$ & \multirow{2}{*}{$\begin{array}{c}\text { GÉPELEMEK } \\
\text { vetületi ábrázolás, } \\
\text { mühelyrajz, } \\
\text { konstrukciós tervezés } \\
\text { és anyagkiválasztás, } \\
\text { hegesztett kapcsolatok kialakitása, } \\
\text { kötōelemek és alkalmazásuk }\end{array}$} \\
\hline & $\begin{array}{c}\text { Anyagok megmunkálhatósága } \\
\text { öntéssel, szintereléssel, alakitással, } \\
\text { forgácsolással, vágással, hegesztéssel, } \\
\text { forrasztással, ragasztással, } \\
\text { hökezeléssel, felületkezeléssel } \\
\text { Technológiai próbák } \\
\end{array}$ & $\begin{array}{c}\text { Anyagszerkezet-módositó technológiák: } \\
\text { monolitanyag-módositás } \\
\text { (habositás, filcesités), } \\
\text { kompozitgyártás, } \\
\text { hökezelés, } \\
\text { felületkezelés } \\
\end{array}$ & \\
\hline $\begin{array}{c}\text { MÜSZAKI KÉMIA } \\
\text { szerves és szervetlen kémia, } \\
\text { kémiai kötések, egyensúlyok, } \\
\text { reakciók és egyenleteik }\end{array}$ & $\begin{array}{l}\text { Anyagok károsodásállósága: kúszás-, } \\
\text { fáradás-, törés-, kopás-, korrózió-, hō-, } \\
\text { biokárosodás-, öregedésállóság }\end{array}$ & $\begin{array}{l}\text { Technológiatervezés } \\
\text { információforrásai és módszerei }\end{array}$ & $\begin{array}{c}\text { ÁLTALÁNOS GÉPTAN } \\
\text { fizikai mennyiségek és mértékegységek, } \\
\text { fizikai és tapasztalati törvények, } \\
\text { modellek, mérnöki alapmérések }\end{array}$ \\
\hline $\begin{array}{l}\text { BIOLÓGIA } \\
\text { sejttan, szövettan, szervtan, } \\
\text { morfológia }\end{array}$ & $\begin{array}{c}\text { Anyagkiválasztás tervezési, biztonsági, } \\
\text { szabványügyi, minóségügyi, } \\
\text { ökonómiai, ökológiai szempontjai }\end{array}$ & $\begin{array}{l}\text { Technológiák gépesitése, } \\
\text { robotositása, automatizálása }\end{array}$ & $\begin{array}{c}\text { INFORMATIKA } \\
\text { adatfeldolgozás, adatbázisok, } \\
\text { tervezési algoritmusok }\end{array}$ \\
\hline
\end{tabular}

5. ábra. Anyagtudomány és Anyagtechnológia tantárgyak tantervi koncentrációjának tartalmi kivonata

\section{Következtetések}

A felvázolt szempontok és bemutatott példák egyfajta mintául szolgálhatnak a müszaki képzés illetve tananyaga szervezéséhez, nem hagyva figyelmen kívül azt, hogy az egyes tudományágak kellő súlyú „megjelenítése” alapos háttértudást és rendszerező készséget igényel. Jelen cikk ehhez néhány gondolatébresztő felvetéssel kíván „motivációt” adni.

\section{Szakirodalmi hivatkozások}

[1] Lévai Z.: A mérnökképzés algoritmusa és analógiái. Felsőoktatási Szemle, 1988/5. 257-261.
[2] Simon Béláné: Mérnökpedagógiai eljárások az Anyag- és gyártásismeret tanítás-tanulásához. BMF Bánki Donát Gépészmérnöki Főiskolai Kar, Budapest, 2002.

[3] Báthory Z.: Tanulás és tanítás. Tankönyvkiadó, Budapest, 1987.

[4] Nagy S.: Az oktatáselmélet alapkérdései. Tankönyvkiadó, Budapest, 1988.

[5] Bitay E., Bagyinszki Gy.: A müszaki anyagtudomány gyakorlatorientált oktatási struktúrája. In: Fiatal müszakiak tudományos ülésszaka XVI., Kolozsvár/Cluj, Románia, Múszaki Tudományos Füzetek 2011. 47-58. https://eda.eme.ro/handle/10598/14000 